\title{
Design, Crafts and Architecture in Flanders. Do They Relate in Education as in Practice?
}

After World War II the urge for efficiency in the western world splits up the happy traditional marriage between (interior) architecture, arts and crafts and design. The crafts survive as 'hobbies', disengaged from architecture and design which both seek the alliance of industry.

Recent signs indicate that the architectural and design worlds look back to old techniques in search of ornament and narration, influenced by the visual arts and fashion. While in Flanders (Belgium) the disciplines feel the need for a redefinition of their foundations, going back to the source, the Bologna Process pushes higher education in another direction. As a result of the reorganization of arts, heritage and design education, the 'academized' craftsman and interior architect is educated in a more technical-scientific framework, which will likely estrange him from an artistic attitude. This would imply that the artisan qualities currently sought after by architects and various designers will be harder to find, and harder to apply because the designers lack insight in the material foundations of their 'craft'.

This paper aims to express concerns by sketching developments in Belgian education which fail to meet both the interests of designers and wider societal needs. It is concerned with the contributions which arts and crafts might make towards a more engaged and ecological design practice. The demand for the attitudes and sensibilities of craftsman and artist in various sectors of society comes at a time when they are all but lost.

We wish to plea for an approach to education which implements the dynamics of practice and society in order to maintain a dialogue between training and reality. This approach needs to acknowledge the potential synergy between arts and crafts, architecture, heritage conservation and design.

keywords arts and crafts, design, architecture, education, practice

\section{Introduction}

\section{Brief history of a relationship}

In former centuries the connectedness between architecture, arts and crafts, and (later) industrial design was self-evident. Until the first half of the zoth century, western architecture witnesses several apogees of Gesamtkunst which testify to this happy marriage, with or without the backing of industry. Well-known instances are: the Arts and Crafts Movement, Art Nouveau or Jugendstil, Art Deco, the Bauhaus, C.R. Mackintosh, Frank Lloyd Wright etc. Several influential architects such as Henry Van de Velde, Peter Behrens, Le Corbusier and more recently Peter Zumthor, first acquired an artisan or artist training. 
theme 1

theory strand 2

design education in art, craft, technology, and other traditions
After WWII the great concern for efficiency, speed and economic growth in the western world drives a wedge between architecture and the crafts. Modernism becomes popularized but often deteriorates into pragmatism, rationalization and mass prefabrication. Industrial production equals progress. Manual labor, indispensable for the crafts and the arts, becomes unaffordable due to the higher wages in the welfare state, and disappears to the background. The applied or minor arts receive a negative connotation, and in the sixties and seventies of the zoth century are degraded to folklore and hobby. As such they survive. Postmodernism picks up the crafts and reattaches them to design quoting from history and rehabilitating ornament. Counterculture movements helped revive the crafts. The interest renewed, the applied arts in the Low Countries adopt a new name: creative craft (scheppend ambacht). Part of the applied arts emancipate into major art: ceramics and glass artists, e.g. the Studio Glass Movement, call themselves sculptors. The crafts are also reintroduced in industrial design, but the connection with architecture has largely vanished. Design and craft objects are now being exhibited autonomously in a museum setting rather than integrated in an interior. From the eighties onward the participation of industry grows again and design acquires wide public interest. In its aspiration towards unique pieces it looks for a liaison with art as well as with handicrafts, sometimes inspired by pre-industrial culture(s) (Gimeno-Martinez and Floré 2010: 226-281 and 282-345). From ca. 1995 design objects are omnipresent in the architectural interior, albeit mostly as an affirmative addition rather than part of the architectural design and realization process.

Recent trends in society rekindled the connections between design, art and craft. Arguably the two main factors are the quest for sustainability and the demand for uniqueness, which in the context of global serial production represents luxury. Architecture meanwhile, after neo-minimalism and attempting to re-evaluate Modernism, goes in search for lost attitudes and qualities associated with tradition and craftsmanship, for instance under the motto 'Full of heritage and without historicism' (Grafe, Pimlott and Stuhlmacher 2002: 5).

\section{The resurgence of craft}

Since the early 2000's numerous products in the field of industrial design express relationships with craft and art. The exhibition [Im]Perfect by Design, at the 4 th Design Triennial in Brussels presents examples of this evolution to illuminate traditional and artistic sources of inspiration for design creativity. The catalogue identifies a crossover process which redefines the relations between the disciplines. In the love-triangle between art, craft and design the positions are no longer hierarchical or clearly defined (Pil 2004: 19). Bram Boo for instance made a series of prototypes covered in jute (Fig. 1) to research the impact of imperfections, roughness and uniqueness on consumers expecting perfection.

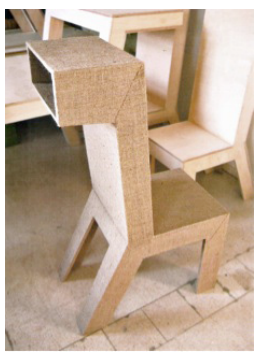


The influence of education is illustrated by a prototype entitled Reinventing Functionality (Fig.2) by Joris Laarman. A radiator as pure ornament. As such it can become larger and optimize its functionality, reconciling modernism with post-modernism. A kind of graduation project unthinkable in a scientifically oriented design school (Smets 2004: 34).

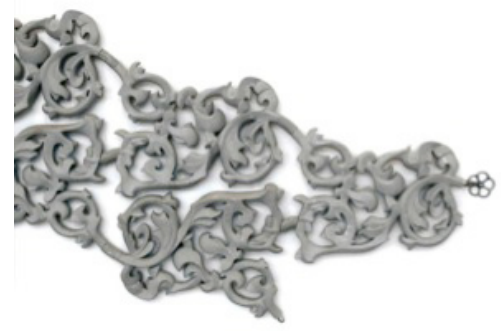

Figure 2.

Reinventing Functionality or Heatwave Radiator (2003), Joris Laarman.

A year later, in 2005, the Dutch architecture journal Oase \#65 is entitled 'Ornament'. It presents an investigation of design approaches using knowledge of architectural traditions, sometimes including the application of decorative visual information in new ornaments. One of its editors, Christoph Grafe, now head of the Flemish Architecture Institute (VAi), organizes in 2014 the exhibition 'Pasticcio' in deSingel in Antwerp. Grouping seven contemporary European architects outside the mainstream, it is a critique of the loss of quality and intimacy caused by globalization and a demonstration of how contemporary architecture can deal with this if it is based on continuity. In the exhibition a house is shown by Bovenbouw Architecten with an elaborate brickwork façade which expresses the internal layout (Fig. 3). It seems at the same time an homage to modernist architect Alvar Aalto and to traditional Belgian brickwork.

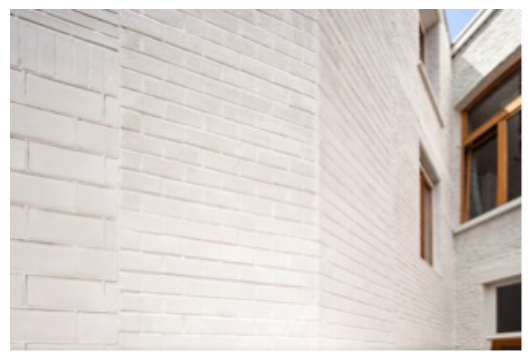

Figure 3. House extension Mortsel (2012), Bovenbouw Architecten, photo: Karin Borghouts.

Also in 2014 Oase \#92 Codes and Continuities deals with the same concerns and can be seen as the accompanying publication to the exhibition in deSingel. The editors suggest there exists a lineage of non-organised architects that demonstrate alternative sensibilities and attitudes, and use tradition to rearticulate the modern. Instead of emulating the ideals of the architectural avant-garde, they seek to accommodate change by artfully applying existing codes and conventions (Avermaete et al. 2014: 6). Vittorio Lampugnani counters the idea that innovation equals improvement. Considering architecture as a craft he argues the concept of modernity makes no sense, because it implies a break. 'So we find we are, almost despite ourselves, irremediably modern. For modernity (...) is not a choice of style, it is a condition.' (Lampugnani 2014: 21-22) In his contribution Grafe suggests that precisely this quality characterizes Flemish and Belgian architecture, accommodating traditional social structures (Grafe 2014: 161). 


\section{The crafts in reformed higher education}

In the Low Countries design practices are in search of ornament, narration and cultural identity through old techniques as they stand on the brink of extinction. While the borders between the visual arts, design, fashion and architecture are regularly crossed and do not hinder crosspollination, the disciplines behave as insular domains. Meanwhile the need for (re)definition of the foundations of disciplines such as (interior) architecture, visual arts and conservation and restoration, is clearly felt for the purposes of education and practice. The current reorganization of the art and architecture education in Flanders however causes the knowledge of artisan techniques and attitudes among graduates to decline. Though no comprehensive study has been made on the condition of the crafts in Flanders, some examples illustrate the tendency.

With the gradual disappearance of the historic art and architecture institutions under the Bologna Process on higher education (started in 1999) the tradition or intangible heritage of these schools also disappear. Founded in 1663, the oldest art academy in the Low Countries, The Royal Academy of Fine Arts of Antwerp, used to host the education of architecture, fine arts, fashion and conservation and restoration, with strong traditions of academic art education. Architecture and Interior Design left the unit some years ago to eventually become part of the University of Antwerp in 2013. In the same year the new constellation of the remaining Academy split up again, the departments of Fine Arts and Fashion choosing to join the School of Arts as part of Artesis-Plantijn University College, the department of Conservation and Restoration joining the University of Antwerp (Ubben, Pas, Theys 2013 and De Vos, Lombaerde 2013). In the new program of Conservation and Restoration, art history is reduced to a vague component within the course 'Object and Context'. Specific histories of art on different materials, such as the history of sculpture for the disciplines stone and wood, disappear from the curriculum and the famed studio sessions with individual supervision are diminished by half. Courses such as chemistry take over. The consequence is that the 'academized' craftsman from now on receives an education from a technical-scientific perspective, which will lead him towards a less artistic attitude and less historic awareness. This would imply among other things that the qualities which architects increasingly seek in building partners, will be ever harder to find, even in the historicizing or heritage conservation context. Artisan techniques, old or new, are only taught now in Belgium in non-regular courses or in parttime art education. These courses are intended for recreational not professional use. In the construction sector there is a desperate shortage of capable craftsmen who master restoration techniques, a problem for heritage conservation, or artisan techniques, a problem for architectural design (Cassiman 2012: 113).

The Belgian Saint-Lucas Schools for architecture and fine arts were founded in Ghent in 1863 and later opened schools in many major cities. The Saint-Lucas Visual Arts Department of Ghent and Brussels became in this academic year, similarly to Antwerp, part of the LUCA School of Arts. The Saint-Lucas architecture schools of Ghent and Brussels on the other hand, which have a very strong tradition of craftsmanship combined with creativity, melted into the Catholic University of Leuven (KU Leuven) new Faculty of Architecture (Heynickx, Schoonjans and Sterken 2013). At a Saint-Lucas School, one of the highlights of the end-of-the-year exhibition of the senior interior designers used to be their furniture design. In the 'academization' following the Bologna Process this part of the curriculum was cancelled in order to distinguish Interior Design from Industrial Design. As a result the graduates of interior design now start their careers without having designed a single piece of furniture. In a compensation attempt master students of interior design 
were asked in January 2014 to present their work on a 'presentation table' they had to design themselves without any prior craft education. The situation is slightly better at the Faculty of Architecture at the University of Antwerp, but the tendency is typical. In the Architecture Sciences course in Antwerp the identity of the discipline Interior Architecture is a prominent issue, and the interdisciplinary relation between crafts, design and architecture is clearly present in the PhD research topics.

These evolutions are imposed top-down onto the institutions, which are hastily (and partly intuitively) addressing the problem, motivated also by budget cuts and staff reductions. To fulfill the dictated, abstract goal 'to perfectly combine theory and practice' in order to face the challenges of the profession seems to be more and more difficult without each school losing its identity. The ERASMUS program and the Bologna Process make safeguarding the identity of each 'school' and developing a collaboration based on differences into a challenging task (Boutsen, 2013).

\section{A call for collaboration}

The interdisciplinary connections between crafts, design, visual arts and (interior) architecture are without a doubt an urgent theme in education and practice. The specific connection between the crafts, design and architecture, mutually and in relation with higher education, has not yet been researched. The traditional academic vocational training which survived the destructive 1990's and which combined with an open attitude towards the newest artistic developments made the Flemish educational landscape unique (e.g. fashion) is now threatened.

This paper wishes to advocate a dialogue between the sectors and the new courses, in order to maintain and stimulate the dynamics between reality and education. In this way it might be possible to breathe new life into the essential synergy between the defining fields of material culture that the real world demands.

\section{References}

\section{Books}

Ornament, (2005), Oase \#65, Naio10 Publishers.

Gimeno-Martinez, J. and Floré, F. (eds.), (2010), Design and Craft: a history of convergences and divergences, 7th Conference of the International Committee of Design History and Design Studies (ICDHS), 20-22 September, Brussels: Contactforum. De Vos E., Lombaerde, P. (eds.), (2013), 350 jaar architectuur in Antwerpen [350 years of architecture in Antwerp], Antwerp/Brussels: UPA/ASP.

Heynickx, R., Schoonjans, Y. and Sterken S. (reds.), (2013) Tekenen en betekenen Opstellen over het architectuurinstituut Sint-Lucas, 1862-2012 [To design and to signify. Essays on the institute of architecture Sint-Lucas], Leuven: University Press.

Ubben, E., Pas, J., Theys, H. (eds.), (2013), CONTRADIcTIES. Koninklijke Academie voor Schone Kunsten Antwerpen 2013-1663 [CONTRADICTIONS. Royal Academy of Fine Arts Antwerp 2013-1663], Antwerp: AsaMER

Codes and Continuities, (2014), Oase \#92, Naio1o Publishers

Figure 1:

From [IM]PERFECT by DESIGN, exh. cat., Royal Museum of History and Art Brussels, p. 79. 
Figure 2:

From [IM]PERFECT by DESIGN, exh. cat., Royal Museum of History and Art Brussels, p. 31. Figure 3:

From http://hicarquitectura.com/2014/03/bovenbouw-house-extension-mortsel/

\section{Articles}

Grafe, Ch., Pimlott, M. and Stuhlmacher, M., (2002), "Editorial: ornament. Decorative Traditions in architecture", Oase \# 65, pp. 2-5

Pil, L., (2004), 'Ongewone designconcepten/Design insolite/Unusual Design Concepts', in [IM]PERFECT by DESIGN, exh. cat., Royal Museum of History and Art Brussels, pp. 13-30, pp. 208-215.

Smets, F. (2004), 'Design tussen uitersten: een staalkaart van opleidingen/Les écoles de design: d'un extreme à l'autre/Design between extremes: a training sampler', in [IM] PERFECT by DESIGN, exh. cat., Royal Museum of History and Art Brussels, pp.31-44, pp.216-222.

Valcke, J. (2004) 'De imponderabilia van design. Les impondérables du design', (2004), 'Ongewone designconcepten/Design insolite/Unusual Design Concepts', in [IM]PERFECT by DESIGN, exh. cat., Royal Museum of History and Art Brussels, pp. 5-11.

Avermaete, T, De Bruijn, D. and Floris J., (2014), "Editorial", Oase \#92, pp. 5-11. Grafe, Ch., (2014), "Other Modernities Observations about a North-West-European Architecture", Oase \#92, pp. 150-161.

Lampugnani, V. M., (2014), "Tradition, Subtle Innovation and the Ineluctable Modern", Oase \#92, pp. 21-29.

\section{Unpublished texts}

Cassiman, A.,(2012), Erfgoedgerelateerde opleidingen. Een onderzoek naar het opleidingsaanbod en de scholingsbehoefte $(n)$ binnen de onroerend erfgoedsector in Vlaanderen [Heritage-related training. A study on the educational offer and need(s) within the built heritage sector in Flanders] unpublished study, Artesis University College Antwerp, for the Flamish institute for Built Heritage.

Boutsen D., (2013), Speech of Dag Boutsen, Dean of the Faculty of Architecture, KU Leuven on the occasion of the establishment of the Council of the Faculty. 